\title{
Research on EGP+ ESP Model Construction in Col lege English Teaching Based on Network Informati on Technology
}

\author{
Yuhua Li \\ School of Foreign Languages, Wuhan Textile University, Wuhan, 430200, China \\ email: liyuhua1973@sina.com
}

Keywords: ESP, EGP, college English, Network information technology.

\begin{abstract}
Most colleges and institutions pay more attention to EGP (English for General Purpose) while ignoring the importance of ESP (English for Specific Purpose). However, nowadays, with the increasing needs of interdisciplinary talents who can adapt well to society, traditional EGP teaching has several limitations in college English teaching practice. In order to improve students' comprehensive ability of English utilization and take full advantage of network information technology, the author puts forward a new mode of college English teaching -- EGP plus ESP mode. It will improve students' ability of combining professional knowledge and English, and strengthen the leading role of modern educational technology in the curriculum reform. Besides, this study will also improve the efficiency of college basic courses teaching and cultivate all-round developing interdisciplinary talents.
\end{abstract}

\section{Introduction}

Network-assisted instruction is to integrate information technology and various subjects. That means, it incorporates network information technology and various subjects in the teaching process and fully integrates the technology into the curriculum structure, curriculum content and curriculum resources. [1] In this way, different segments such as network information, curriculum content and curriculum implementation could highly and harmoniously work together which will better accomplish the learning goals of the teaching objectives, curriculum objectives and students. [2] At present, EGP and ESP are two main streams of English teaching in China. EGP refers to the Basic English knowledge taught in schools. [3] It mainly emphasizes students' comprehension of the basic language structure (vocabulary, grammar, etc) of English and the cultivation of the five basic skills (listening, speaking, reading, writing and translation). [4]ESP courses refer to those made for students according to the learner's specific needs and purposes, which aim to enable students to utilize language in specific work environment. Usually, ESP courses include marketing English, legal English, tourism English, financial English, business English, foreign trade English, medical English etc. In other words, ESP teaching attaches great importance to enhance learners' practicability and ability to apply English to specific field.

However, the ESP English teaching is almost blank in our country. In the process of English teaching, there is barely any practicality and applicability of language. With the increasing numbers of college English optional courses for higher learning, many domestic experts, such as Zhang Zhenbang, Qin Xiubai, Cai Jigang, Lu Jianming, they think that the curriculum setting of college English and teaching focus should shift from the EGP mode to ESP mode. And the English teaching should mainly focus on academic needs and other specific needs. [5]ESP teaching mode has become the main way to achieve this purpose, namely, to cultivate interdisciplinary talents who know both English and professional knowledge. [6]In ESP teaching, English language is treated as the tool for professional communication which provides more convenience for professional service. 


\section{The necessity of integrating EGP plus ESP teaching mode based on network information technology}

Nowadays, in many universities and institutions, the extensive application of information technology in English teaching and the reform of College English teaching have become the favorable conditions for the implementation of EGP plus ESP teaching mode. The introduction of network resources into college English classroom is the inevitable trend of English teaching development. For example, Sina has reported news, "Fudan University has opened the CAI classroom, which is open to students throughout the day, and students can use English teaching software for listening and speaking training."

Then, there are many different views on the integration of network information technology and curriculum. Some researchers believe that integration can be divided into discipline integration, media integration and integration among teachers and students. The Beijing Normal University professor He Kekang said: "under the guidance of advanced education thought and theory, especially the Predominance to Main body theory, computer networks and multimedia technology should be the tools for promoting students' autonomous learning awareness and emotion, and also the tools for creating better teaching context. [7]These tools should be comprehensively applied into the teaching process of various subjects to make teaching resources, teaching elements into collation, combination and integration. After the overall optimization, the goal of cultivating students' innovative spirit and practical ability could be achieved. The premise and condition of realizing the integration of information technology and English teaching is digital hardware and software environment, such as digital classrooms, electronic reading rooms and teaching application software platform, digital management system, teaching resources and so on, all these can create conditions for students to learn ESP. [8] First of all, teachers should make full use of BBS, message boards, e-mail, chat room, Blog and other network services. In this way, students can have practical application while they are learning English, so that they can really apply what they have learned. Secondly, teacher should effectively integrate network information technology and college English EGP plus ESP teaching mode. To achieve this goal, teachers need to create EGP plus ESP hierarchical teaching mode. [9]Therefore, teachers should fully mobilize the enthusiasm of students, so that they can learn and master English efficiently and happily. It is also better to construct a new teaching mode which combines credit system, examination and technical title certification and hierarchical teaching. In conclusion, college English educators should make full use of network information resources and teaching practice, and then make research on the efficiency of this teaching mode and the influence factors of students' English application ability in their learning process, and finally form a relatively complete theoretical system.

\section{The feasibility of integrating EGP plus ESP teaching mode based on network information technology}

EGP and ESP are two major branches in contemporary English language teaching. EGP (General English) is typical language teaching course, it refers to the English language courses which treat cultivating basic language skills as the purpose. The teaching content mainly includes the explaining and training of the language which can lay a good language foundation for students.

The ESP courses are opened according to the needs of the learners who will be engaged in future occupation. The purpose is to improve the ability of English learners so that they can skillfully use language in working environment. Strevens proposed four distinctive features between ESP and EGP: (1) to meet the specific demand of learners; (2) the ESP course content is related to specific profession and occupation; (3) the use of language vocabulary, syntax and discourse happens in the specific activities of the relevant professions and occupations; (4) different from EGP, ESP mode is a kind of teaching mode with clear teaching aim, strong pertinence and practicability. It is really close to ability cultivating and occupation. It treats students as the center and the language as the tool. And there are so many kinds of ESP courses, since we've already given a lot of examples here, 
so we don't repeat it any more. It is actually the follow-up of college English. ESP courses teach students the English which is related to their majors. The purpose of it is to cultivate students' English practical ability to work in a certain environment. Obviously, there are some differences between ESP and EGP in teaching content and purpose. It's not enough for students to learn only basic English or learn some additional specialized English in the fast growing society. Therefore, the integration of EGP and ESP is the inevitable result of social development.

The author thinks that ESP teaching can be used as a continuation of EGP teaching. After students finish the learning of EGP courses, educators can open diversified ESP optional courses according to specific purpose of students. In this way, students' ability of combining professional knowledge and English could be promoted and enhanced.

\section{Construction of college English EGP plus ESP mode based on network information technology}

Based on the exploration of the reform of college English teaching and university personnel training, we think that in the background of internationalization of higher education, college English teaching should strengthen ESP teaching, combine the EGP and ESP, and finally achieve the effective use of EGP plus ESP teaching mode. EGP teaching focuses on strengthening students' basic knowledge, and ESP teaching highlights the practicality of English language. In fact, EGP and ESP are two levels of the same teaching goal. In the first year, educators concentrate on strengthening EGP Basic English teaching and training five Basic English skills. In the third and fourth semester, educators implement EGP plus ESP teaching mode. Specifically, integrating ESP teaching into EGP teaching step by step, such as teachers provide professional knowledge teaching, reading and translating activities to strengthen and enhance students' learning of basic knowledge. At the same time, it is suggested that in the third and fourth year, ESP elective courses should be set up in the whole school teaching.

Therefore, the author thinks that students who got CET4 and CET6 certificates in the first two years of their college life and finished the college EGP courses can choose the ESP courses which can meet their future demand after their graduation. At the same time, the school should offer diversified elective courses according to the specific needs of the learners. Specifically, if the student intends to continue postgraduate studies, students can focus on elective academic English courses in the third and fourth year of their college life. In the elective academic English courses, they can improve their ability of professional literature searching and reading, lectures listening and international communicating ability. In this way, these elective academic courses could lay the foundation for their future academic career. Students who choose to work after graduation can focus on the cultivation of professional English ability which includes the ability of absorb and exchange professional information in English and prepare for future work. We can try to construct the College English teaching mode as shown in figure 1.

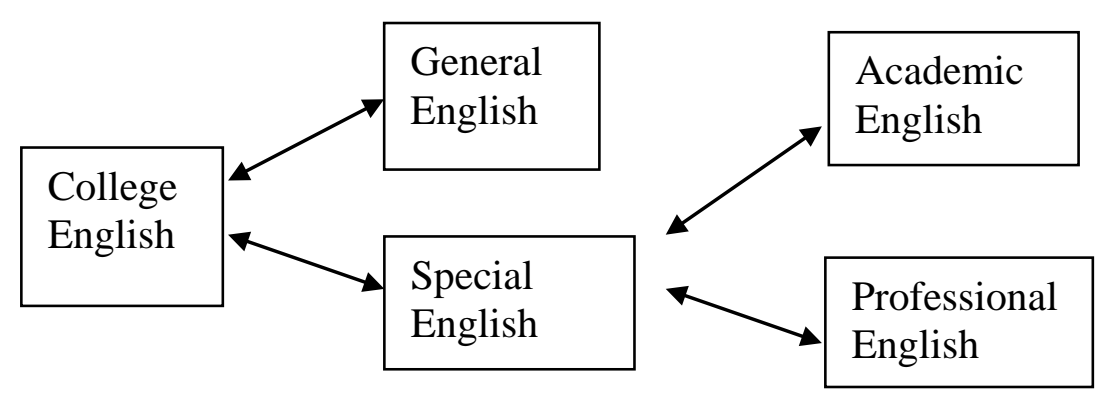

Figure 1.Construction of college English EGP plus ESP mode 


\section{The advantages of integrating EGP plus ESP teaching mode based on network information technology}

\subsection{Meeting the individual needs of students and social development needs}

After China's accession to the WTO, the requirements for graduates are constantly improved, and the demand of English ability has shown specialization and diversification, the common foreign language skills has been difficult to meet the market demand. Foreign language is becoming more and more professional, practical and instrumental. However, many students lack professional English knowledge after graduation, so they can not understand the professional English materials or drawings, and finally they can not meet the needs of society. To solve this problem, the EGP plus ESP teaching mode has changed the old English teaching mode which emphasized basic skills but ignored the practicability. This teaching mode take the curriculum mode which put basic skills as the basis and professional knowledge as the improvement, so as to meet their individual needs and needs of social development to the maximum extent.

\subsection{Strengthening the link between EGP and ESP teaching}

General purpose English lays the foundation for the study of special purpose English learning and special purpose English learning deepen the learning of general purpose English. Paying attention to EGP learning, laying a solid language foundation, mastering the basic knowledge of English, having good listening, speaking, reading, writing and translating ability, taking professional and strong ESP course training, all these could encourage students to focus on basic English learning as well as the professional knowledge integration, and finally meet students' studying needs and future working needs to the maximum extent.

\subsection{Stimulating students' learning motivation to achieve better learning efficiency}

The "automatic motivation theory" of educational psychologist G.W.Allport pointed out: "if a student has a kind of motivation in learning process, he would establish self-confidence, promote effective learning and make greater achievements because of the automatic role of motivation no matter what grades he gets." EGP plus ESP mode makes English learning and professional integrated together, gives students clear learning objectives, and enhance students' future development. The great power could fully mobilize the initiative and enthusiasm of students' learning and achieve better learning effect.

\section{Conclusion}

The ultimate goal of integrating EGP and ESP teaching mode based on network information technology is to train application-orientated interdisciplinary talents. Through this teaching mode, students can not only have a solid foundation of language, but also can meet the needs of social development. We believe that under the guidance of College English Curriculum Teaching Requirements and with the joint efforts of college English teaching staff, EGP plus ESP teaching mode will be successfully improved and implemented, and more and more high-quality applied talents who have both professional knowledge and language ability will be raised.

\section{References}

[1] TEACHING THE COMMUNICATIVE USE OF ENGLish[J] . J. P. B. Allen,H. G. Widdowson. IRAL - International Review of Applied Linguistics in Language Teaching . 2009 (1-4)

[2] Seeing the wood AND the trees:Some thoughts on language teaching analysis. Stern $\mathrm{H} \mathrm{H}$. The Second Language Curriculum . 1989

[3]Towards a Theory of Instruction. Bruner JS. Journal of Women s Health . 1966

[4]Some propositions about ESP. Carter,D. The ESP Journal . 1983 
[5]Teacher development and educational change. Fullan M,Hargreaves A. Teacher Development and Educational Change . 1992

[6]Strategies in Learning and Using a Second Language. Cohen A D. Journal of Women s Health . 2000

[7] ESP:Criteria for Course Design. Widdowson,H.G. Methodology in TESOL .

[8] Principles and Practice in Applied Linguisties. Cook Guy,Seidlhofer Barbara. Journal of Women s Health . 1995

[9]Course Design: Developing Program and Materials for language learning. Dubin F,Olshtain E. Journal of Women s Health . 1986 